\title{
The Industry 4.0 Induced Agility and New Skills in Clusters
}

\author{
Marta Götz \\ Associate Professor, m.gotz@vistula.edu.pl \\ Vistula University, ul. Stokłosy 3, 02-787 Warsaw, Poland
}

\begin{abstract}
$\mathrm{T}$ he fourth industrial revolution (Industry 4.0) transformed global value chains by transforming them into adaptive networks of enterprises. To remain competitive, companies need to integrate themselves into these networks, which require increased flexibility in terms of reorganizing business structure and expanding the portfolio of competencies. This article attempts to find ties between the concepts of Industry 4.0

and clusters. This new viewpoint helps one discern the role clusters play in the development of necessary skills as part of this nww context. Spatial proximity provides unique opportunities for such interactions, which cannot be imitated by remote digital technologies. As a result, clusters, while meeting certain requirements, will not lose their relevance in the context of Industry 4.0, but, on the contrary, become its key driver.
\end{abstract}

Keywords: fourth industrial revolution;

Industry 4.0; cluster; networks; global value chains;

agility; skills
Citation: Götz M. (2019) The Industry 4.0 Induced Agility and New Skills in Clusters. Foresight and STI Governance, vol. 13, no 2, pp. 72-83. DOI: 10.17323/25002597.2019.2.72.83 
$\mathrm{I}$ ndustry 4.0 or the fourth industrial revolution is sweeping the globe, mainly across developed economies, and is gaining the attention of policymakers, in business circles, and among industry representatives and scholars [Schuh et al., 2014; Hermann et al., 2015]. Researchers who started dealing with this digital transformation agree on the scale and scope of changes that the fourth industrial revolution would cause. The need to respond to the challenges presented by these transformations calls for major modifications of policy plans, industry strategies, business models, production methods, value chain governance, and attractiveness of places [UNCTAD, 2017]. The experts, however, disagree as to whether Industry 4.0 is indeed the fourth revolution or just the next stage of the previous one [Alcácer et al., 2016]. Most available papers deal with technical, engineering, managerial, or strictly business aspects of this profound transformation [Kagermann et al., 2013; Drath, Horch, 2014; Brettel et al., 2014; Lydon, 2016]. To the best of author's knowledge, the literature linking Industry 4.0 with clusters is almost non-existent [Götz, Jankowska, 2017]. A systematic approach to the Industry 4.0 has only been emerging gradually [Liao et al., 2017]. Industry 4.0 is supposed to have a profound impact upon Global Value Chains (GVC) and international production [Folkerts-Landau, Schneider, 2016; Alcácer et al., 2016; Strange, Zucchella, 2016; UNCTAD, 2017]. It implies a shift towards highly adaptive networks of integrated entities [Kagermann et al., 2013]. In such an environment, companies would be required to display a high level of agility - the ability to orchestrate various activities and competences and swiftly become insiders of certain chains and networks with employees equipped with a new set of critical skills (Figure 1). Clusters, as hybrid form of organization, epitomizing the simultaneous cooperation and competition (coopetition) might offer conducive conditions for the ongoing digital business transformation and help equip employees with the necessary
Figure 2. Cluster role in Industry 4.0

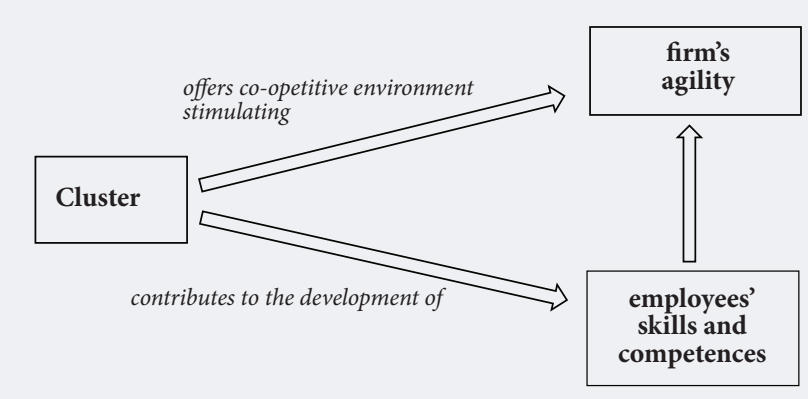

Source: author.

competences and skills (Figure 2) [Alcácer et al., 2016; Sajdak, 2014; UNCTAD, 2017; ASTOR, 2017].

This paper will attempt to shed light on existing relations and advance our understanding of the role of clusters in the realms of digitally transformed production. It identifies the relationship between these two by making the reference to networks, GVCs, and the concept of agility which is derived from a set of specific employees' skills. The paper relies on various sources. Besides the literature review (dominated by IT and industry specific papers ${ }^{1}$ ), business media and industrial magazines from Poland ${ }^{2}$ and abroad ${ }^{3}$ as well as insights gathered from experts have been employed ${ }^{4}$. Consultations with selected industry and academic representatives took place in the middle of 2016 in the form of semi-structured phone calls and direct interviews as well as the exchange of emails. The main topics discussed within interviews are presented in Table 1.

The results of these interviews are presented and discussed throughout the paper to corroborate and strengthen the claims made. This manuscript should

Figure 1. Changes Triggered by the Fourth Industrial Revolution and Their Relation to Clusters

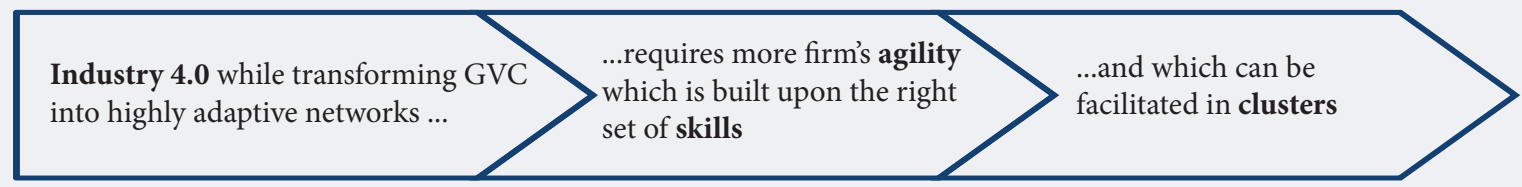

Source: author.

\footnotetext{
The researchers only started dealing with the entrepreneurial angles of Industry 4.0

${ }^{2}$ Available in Polish media, the opinions and comments expressed by experts responsible for the digitalization and implementation of Industry 4.0 - R. Grucza, vice chairman REC Global; M. Kaczurba - Enterprise Partner Manager, Microsoft, T. Jadczak, chair in SAP Asseco Poland, R. Krawczyński, Oracle Polska, D. Lis, director in Transition Technologies SA, Poland Solution Center, B. Kamiński, partner in Infovide-Matrix, M. Pawlik - director in BPSC.

3 Publicly available and quoted opinions of representatives of Siemens, Volkswagen, Baluff, Rec Global, and Mercedes.

${ }^{4}$ Consultations with professors B. Kamiński (Warsaw School of Economics), J. Gracel (ASTOR), B. Woliński (Siemens), Z. Piątek (Przemysl 4.0)
} 


\section{Table 1. Topics for Interview}

\begin{tabular}{|c|c|}
\hline Thematic Category & Questions to Discuss \\
\hline $\begin{array}{l}\text { Factors critical for the } \\
\text { development of Industry } 4.0 \\
\text { and major challenges }\end{array}$ & $\begin{array}{l}\text { Technical dimension (quality of bandwidth and network security) } \\
\text { - Segal aspects (regulations, standards, norms) } \\
\text { - } \text { educal aspects (such as the elimination of many professions and high demand for skilled and } \\
\text { - Main issues raised in the context of Industry } 4.0 \text { induced challenges - how will they play out within } \\
\text { and among countries? }\end{array}$ \\
\hline $\begin{array}{l}\text { Competitiveness in light of } \\
\text { Industry } 4.0\end{array}$ & $\begin{array}{l}\text { - What is/will be crucial determinant of competitiveness and future international cooperation within } \\
\text { the value chains in the face of Industry } 4.0 \text { ? } \\
\text { - The alignment of legal aspects (international regulations), the technical solutions (transmission } \\
\text { security), or rather the individual capabilities of specific companies - which solutions would become } \\
\text { critical factors for their adjustment in the field of Industry } 4.0 \text { ? }\end{array}$ \\
\hline Reconfigurations and risks & $\begin{array}{l}\text { - Can traditional suppliers and partners be at risk if they cannot keep up with the progress in } \\
\text { automation, digitalization? } \\
\text { - How can the current business relations be reshaped? } \\
\text { - What is the risk of eliminating those who cannot adapt? }\end{array}$ \\
\hline $\begin{array}{l}\text { Asymmetry and } \\
\text { monopolization of benefits }\end{array}$ & $\begin{array}{l}\text { - Do these developments and new business models increase the (over)dependence upon suppliers? } \\
\text { - Are there benefits for the leader or pioneer who adapts certain solutions on the basis of a quasi- } \\
\text { monopoly («front runner»)? }\end{array}$ \\
\hline $\begin{array}{l}\text { Accurate capturing of } \\
\text { Industry } 4.0 \text { advancements }\end{array}$ & - How does one approach the exploration of Industry 4.0 progress in an international context? \\
\hline \multicolumn{2}{|c|}{$\begin{array}{l}\text { Note: }{ }^{*} \text { - Available data and indicators such as the one on the development of broadband networks, or the use of computers, etc. only suggest the } \\
\text { conditions / potential for Industry 4.0, but do not inform about companies' actual capabilities to transform business models. }\end{array}$} \\
\hline$S$ & \\
\hline
\end{tabular}

be regarded as explorative study; a conceptual consideration and reflection upon the selected aspects of ongoing digital transformation. It outlines the pattern of relationships between Industry 4.0 and the geographical concentration of activities in the form of a cluster, in particular the advantages it can offer for firms to be agile and employees to possess the right set of skills critical for advancing the digital transformation.

\section{Conceptual Definitions of Industry 4.0 and Clusters}

Despite the growing popularity of the fourth industrial revolution there is still a lack of effort to systematically review the state of this wave of digital transformation [Roblek et al., 2016; Liao et al., 2017]. Institutions define the term differently, highlighting selected elements (see Table 2). In general, Industry 4.0 is also de- picted as a government-sponsored vision for advanced manufacturing and a strategy for re-industrialization. Industry 4.0 encompasses among other things autonomous advanced robotics, augmented reality, additive manufacturing, artificial intelligence, big data, and cloud computing. Key elements of this transformation can be also summarized as decentralized intelligence, rapid connectivity, context integration in real time, and the autonomous performance of tasks [Immink, 2015; Bosch, 2015].

Industry 4.0 constitutes a specific amalgamation of concrete IT solutions, a unique set of engineering, and the combination of computer science with management. The digitalization of traditional industrial sectors thanks to Industry 4.0 leads to the gradual disappearance of borders between plants, branches, firms, or even geographical areas. Whereas scholarly papers

\section{Table 2. Some Definitions of Industry 4.0}

\begin{tabular}{|c|c|c|}
\hline Organization & Definition & Sources \\
\hline $\begin{array}{l}\text { German Industry Association (Bundesverband } \\
\text { der Deutschen Industrie, BDI) }\end{array}$ & Fourth industrial revolution & [BDI, n.d.] \\
\hline Germany Trade \& Invest (GTI) & $\begin{array}{l}\text { A paradigm shift from "centralized" to "decentralized" } \\
\text { production and envisages that the product communicates }\end{array}$ & [GTI, n.d.] \\
\hline McKinsey & Next phase in the digitization of manufacturing & [Manyika et al., 2016] \\
\hline SAP & $\begin{array}{l}\text { A collective term for technologies and concepts of value } \\
\text { chain organization }\end{array}$ & [SAP, 2017] \\
\hline European Parliament & A group of rapid transformations & [Smit et al., 2016]. \\
\hline
\end{tabular}


touch mainly upon the technical aspects, the dossiers drafted by international organizations and think-tanks revolve around the expected benefits and challenges this revolution might bring about, there is still little understanding of the spatial dimension of Industry 4.0 and hence, of the role of clusters as providers of a conducive environment for agile firms and skilled workers. Clusters are spatial hubs of linked companies, specialized suppliers, service providers, and associated institutions in a particular field that are present in a nation or region [Porter, 2000]. Despite the popularity in academic as well as policy circles, the cluster concept is sometimes criticized as being too imprecise [Pedersen, 2005]. The basic features of clusters are presented in Table 3.

\section{The Digital Transformation of Global Value Chains and Networks}

Industry 4.0 stipulates the digital transformation of production, smart dispersed manufacturing, self-optimizing systems, and the digital supply chain in the information-driven cyber-physical environment [Brettel et al., 2014]. It means the organization of production processes based on technology and devices autonomously communicating with each other along the value chain [Smit et al., 2016]. It also heralds a new model of collaboration and incarnates the idea of "connected enterprise" where almost everybody is cooperating with each other along the value chain. Advances in ICT have supported new governance mechanisms in GVCs and shape modern global networks supported by foreign direct investment [Foster, Graham, 2016]. Whereas some studies [Rangan, Sengul, 2009] argue that ICT adoption facilitates control in outsourcing, thanks to the constant information exchange; others associate ICT with higher in-house production [Chen, Kamal, 2016].

New forms of cooperation and competition as well as new solutions with a reduced share of mechanics and hardware in the overall customer value proposition are emerging in the digital era [UNCTAD, 2017; Mikusz, 2014]. Particularly, previously isolated business models of the traditional goods-producing industry meld together with those of software businesses. Customeroriented business models characterized by interactive value creation with users and other external actors as well as innovative processes that are realized in inter- organizational networks are becoming key competitive factors. The powerful consequences of digitization and additive manufacturing entail the transformation of economies of scale into economies of scope, and the production of any object in any place. Interdisciplinary technologies brought by the fourth industrial revolution will create new business models based on manufacturing as a service (MaaS). New technologies enable turning manufacturing companies into service providers as consumers might be interested in simply using the product but not necessarily owning it [Kumar et al., 2016]. Companies can "rent" production capability and capacity as needed without the need for providing the final product. Besides, large companies that can take advantage of their scale and data insights tend to add new business lines, which leads to their expansion and is increasingly blurring the traditional sector boundaries amid the complexity of GVC governance [Manyika et al., 2016]. It can be argued that the fourth industrial revolution not only transforms the architecture and organization of value creation, but it also moves the logic of production from the simple chain of activities adding value to networks and further to platforms of value creation. Clusters might be regarded as the nodes of global production networks or cores on modern industry platforms [Götz, Jankowska, 2017].

The aforementioned characteristics and features of modern production systems and digital transformation in fact embody many of the properties of clusters. Intense cooperation in various constellations, sharing know-how, iterative upgrading processes, melting processes, and connecting tasks and yet fragmenting them as well as harnessing available suppliers: all these resemble the attributes of full-fledged clusters with specialized entities collaborating and competing along the value chain, outsourcing certain functions when necessary or merging others when more suitable. The capacity to create and seize value would depend upon building new networks and becoming an insider thereof. The ability to swiftly join existing networks of collaborating entities would therefore be crucial for participating in Industry 4.0 global value chains.

Industry 4.0 epitomizes the business-to-business (B2B) interface of digital transformation [Hüther, 2016]. It refers to interactions among firms in a highly-digitalized network functioning in the combined manufacturingservice production. This implies that the production chain binds tightly successive stages thanks to the

\section{Table 3. Main Features of Clusters}

\begin{tabular}{|c|c|}
\hline Definition & $\begin{array}{l}\text { - Useful instruments in regional and development policy that epitomize coopetition, create synergies, } \\
\text { foster innovativeness and competitiveness [Njøs et al., 2016] } \\
\text { - Hybrid forms of long-term contracting and reciprocal trading [Maskell, Lorenzen, 2003] }\end{array}$ \\
\hline $\begin{array}{l}\text { Attractive features [Porter, } \\
\text { 2000; Ketels, 2004; } \\
\text { Brodzicki, 2005; Götz, } \\
\text { 2009] }\end{array}$ & $\begin{array}{l}\text { - Superior competitiveness and innovativeness } \\
\text { - Conducive knowledge environment stimulating learning } \\
\text { - Institutional setting possibly reducing uncertainty and transaction costs }\end{array}$ \\
\hline
\end{tabular}


high-quality connectivity that guarantees the availability and fast flow of information. This leads to dense networks. Brettel et al. [Brettel et al., 2014] write that collaborative networks are antecedents for cyberphysical systems (CPSs), which are the backbone of the fourth industrial revolution. Network is conceived as a set of reciprocal, reputational, or customary trust and cooperation-based linkages among actors that coalesces to enable its members to pursue common interests [Cooke, 2001, p. 953]. Having the status of "an insider" in relation to a specific business network would become crucial for the firms' existence especially in a highly connected and competitive environment [Forsgren, 2016; Johanson, Vahlne, 2009].

The permanently changing operating conditions of enterprises have put the processes of shaping the competitive advantage into a new light. Ratajczak-Mrozek [Ratajczak-Mrozek, 2010] emphasizes the impact of business networks and their constituents on the competitive advantage of companies on foreign markets. The network approach as a framework for business research has emerged among others because of the technological changes taking place in the B2B market and increased international competition. A business network can be defined as a collection of long-term (formal) and informal (direct and indirect) relationships between two or more entities. No company manages the network or is its "owner", although a single company can take on a strategic position within the network (strategic center). Business networks are paradoxically both stable, durable, and variable as they evolve over time [Forsgren et al., 1995; Johanson, Mattsson, 1987]. Variability is due to the emergence and disappearance of old relationships and is induced by the uncertainty of the environment and the need to respond to emerging opportunities and threats. At the same time, however, the networks are stable as the frequent change of co-operators is difficult due to the high costs of the mutual adaptation processes. Solutions made possible by the digital transformation enable the existence of virtual corporations which are in fact the networks of independent organizations that share competencies with the aim of exploiting a business opportunity $[\mathrm{Da}$ vidow, Malone, 1992]. The ability to leverage the competencies of network members so they can accurately react to market needs should result in sustainable advantages [Christopher, 2000].

Being an advanced form of network cluster offers various benefits which can be attributed to localized demand and supply linkages, available pools of labor market skills, technical and knowledge spillovers transmitted via different channels [Overman et al., 2001]. According to [Sorenson, 2003], clusters are idiosyncratic business networks since whereas firms within traditional networks might be spatially dispersed, firms in clusters operate in a particular location in geographical proximity. This spatial closeness fosters relationships since the frequency of personal contacts can be increased and the social relationships between the actors can be developed. Thanks to the relational proximity, the transfer of knowledge can be facilitated [Rosenkopf, Almeida, 2003]. Clusters present in a given geographic area can network with different regional entities - local companies, laboratories or regional authorities - along the broader value chain.

Summing up, clusters as geographic agglomerations of related industries and associated institutions [Delgado et al., 2014; Marshall, 1920; Krugman, 1991; Ellison, Glaeser, 1997] enable intense network-like relationships and serve as a hubs for industries connected through various linkages, such as knowledge exchange, skills upgrading, input factors' provision, demand, and other associated facilitating institutions [Delgado et al., 2014].

\section{New Skills in Digital Transformation}

Digitalization can indeed offer various benefits, however, these come with strings attached and hidden traps due to the increased complexity [Schmidt et al., 2015]. It affects the entire supply chain from product design and development, through to management and logistics to final distribution [Prause, 2015]. Therefore, it incentivizes firms to rethink existing business models and to figure out new structures. Certain solutions in this respect may be provided by the fractal company with such features as self-similarity, -organization, -optimization, and dynamics [Warnecke, 1997]. A fractal company can be also regarded as a multi-agent system, with fractals monitoring its environment, and making decisions based on the received feedback. Such a mechanism resembles those known in clusters.

Until recently, the overriding aim of a firm was to develop and maintain a long-term competitive advantage without which any competitive position of the company becomes very unstable. However, in the subject literature of recent decades, one can find the view that the importance of long-term competitive advantage decreases [D'Aveni, 1998]. The terms of hyper-competitive, dynamic, aggressive, and intense competition imply that what really matters is flexibility and the ability to immediately adapt to changing conditions or even the capability of doing this ahead of changes i.e. to strike pre-emptively [Romanowska, 2004]. Thus, in a hypercompetitive environment, the lasting competitive advantage is replaced by a series of temporary states of relative superiority [D’Aveni, 1998]. This means that companies, instead of trying to maintain their long-standing competitive advantage as long as possible should instead continuously monitor new ways of maintaining a dominant position in networks. This requires certainly agility skills. Morisse and Prigge [Morisse, Prigge, 2017] mention organizational agility as an important ability in the context of Industry 4.0.

Industry 4.0 can be defined as changeable, agile, reconfigurable, and virtual production [Qin et al., 2016]. This implies manufacturing systems that are intelligent, integrated, and automated as well as those that 
have advanced architecture. It also inevitably leads to changing traditional production relationships among suppliers, producers, and customers as well as the relationship between the human and machine. This poses a severe threat to laggards, i.e., firms struggling to catch up with ongoing digital transformation [Hessami, 2017; Rüßmann et al., 2015]. It requires the necessary adjustments from all involved parties and the avoidance of becoming stuck in incremental approaches, forcing suppliers in particular to leverage their technologies [Rüßmann et al., 2015]. Firms, being involved in such a modern chain or network relationships should do the following: define which business model to use to leverage upgraded or new offers; build the necessary technological foundation (tool base for analytics); devise and implement the right organizational structure and its capabilities; and participate in and shape technological standardization. In parallel, firms need to build a scenario-based vision of the long-term industry evolution. Such an approach stresses the long term and predictive attitude, though, the importance of the capability of swift and flexible reactions and adaptations to changing conditions cannot be underestimated.

Under the fourth industrial revolution, firms are seen as repositories of competences, knowledge, and creativity, as sites of invention, innovation, and learning [Amin, Cohendet, 2012]. Among the new crucial capabilities that need to be harnessed by firms willing to remain competitive is agility. This complex definition has numerous interpretations. In sum, one can highlight the following basic features of agile companies [Manyika et al., 2016; Meredith, Francis, 2000; Gunasekaran, 1998; Sajdak, 2014]:

- the ability to extract valuable information while working with "big data";

- sensing threats and exploiting market opportunities;

- swift response to change;

- adaptivity to changes;

- openness to new opportunities;

- ability to learn fast;

- decentralization of power, autonomy, and empowerment;

- flexible reconfiguring organizational structure, business processes, tangible and intangible assets;

- swift combining vision and operational management (ambidexterity);

- lean production;

- personalizing offers to customers.

The agility of company must be also regarded first of all as a function of the flexibility and adaptive attitudes of its employees, rather than that of a conducive cluster environment. Industry 4.0 heralds significant challenges for the contemporary labor market. The higher complexity of work would require more flexibility from employees causing simultaneously greater insta- bility. There is a risk of an "hourglass society" with a small and decreasing middle class, the disappearence of medium-salary earners, and growing disparities. Such unequal distribution would obviously affect societies within each country, but it may also play out among countries, where some of them would unfortunately find themselves in this hollowing-out of the middle. In other words, the hourglass society and hollowing-out might play out along global value chains not only within one society. Another risk is the possibility of mass unemployment for some categories of workers, combined with significant shortages of skills in other categories [Mesnard, 2016]. Robotization and automatization may result in a situation where the human workforce becomes dispensable, leading to the need for introducing such compensating mechanisms as universal basic income. Despite these challenges, threats, and risks, the consequences of the digital revolution might translate into more jobs in the long run. Analyses by IW Köln indicate that these adjustments would turn out positive for Germany since approximately one third of the firms undergoing digitalization plan to increase employment and only one tenth predict layoffs [Klös, 2016]. The outcome of these reshuffles is not yet known. In the specialization scenario, where human labor is steering the CPS, gains and positive employment effects can be expected, in contrast to the robotization scenario, which sees human workers only as the extension of digital systems. The fourth revolution undoubtedly would modify the structure of the labor market and although many jobs would disappear, new ones would be created. This poses a huge challenge for education and training systems and, given the high knowledge input, requires close cooperation between business and academia, which is usually associated with full-fledged clusters.

It is impossible to compile a single comprehensive list of skills needed in the age of Industry 4.0. Different researchers and organizations propose various sets of skills focusing on different issues (see examples in Table 4). Generally, in addition to hard skills, there is rising demand for soft skills that are generic personal skills useful within a wide range of professions, such as the ability to be a team player, to foresee possible challenges, to sense partners' and customers' needs, or to adjust quickly to unexpected situations and many others. The right conditions provided by the employers seem critical as well, as shown by the study [ASTOR, 2017]. Črešnar \& Jevšenak [Črešnar, Jevšenak, 2019] argue that the Industry 4.0 business environment would be more open, understanding, collaborative, accepting, and generally more supportive. Much depends on the leadership and management culture, which should foster certain behaviors and attitudes. Unfortunately, such "nudging", guiding, or mentoring are often missing or not fully acknowledged by managers and CEOs. One can suggest that particularly millennials (and their values shaping subsequent attitudes and behavior) might be well prepared for it and also have an impact upon it, as they are in general more inclined toward values 


\section{Table 4. Some Approaches to Defining the Skills Needed in the Age of Industry 4.0}

\begin{tabular}{|c|c|}
\hline Concept & Contents \\
\hline $\begin{array}{l}\text { Generic skills } \\
\text { [Grzybowska, } \\
\text { Eupicka, 2017; } \\
\text { Kinkel et al., } \\
\text { 2016] }\end{array}$ & $\begin{array}{l}\text { - Creativity } \\
\text { - Pntrepreneurial thinking } \\
\text { Problem and conflict solving } \\
\text { - Analytical and research skills } \\
\text { - Tuick adaptation to unexpected situations } \\
\text { The need for courageous action } \\
\text { - Joining forces with one's enemies according to the frenemy principle } \\
\text { - Thick Tearning, unlearning, and relearning }\end{array}$ \\
\hline $\begin{array}{l}\text { Engineer } 4.0 \\
\text { [ASTOR, 2017] }\end{array}$ & $\begin{array}{l}\text { - Strategic thinking } \\
\text { - Interdisciplinary teamwork } \\
\text { - Coording and developing algorithms intuitive for "ordinary people" } \\
\text { - Close monitoring of and learning from competitors and peers } \\
\text { - Analytical skills } \\
\text { - Striving and being motivated by self-development rather than financial benefits } \\
\text { - Openness and activity } \\
\text { - Abenness to diversity, both in terms of contacts with people and tasks } \\
\text { - } \text { Grompt a positive response from listeners } \\
\text { - Striving for perfection }\end{array}$ \\
\hline
\end{tabular}

connected to personal growth, emphasize openness to change, and understand the value of self-enhancement.

\section{Clusters in the Context of Industry 4.0}

There are various challenges and opportunities that arise for clusters due to Industry 4.0. At first glance, there is a contradiction rather than complementarity between two concepts (see Table 5). It may be argued that Industry 4.0 supports the idea that "distance does not matter" and that it suspends the importance of geographical co-location and spatial proximity. The features of internet communications might be perceived as defying the sticky, location-specific offer of clusters. Hence the main risk for clusters is to become an obsolete concept as Industry 4.0 facilitates distant collaboration and reduces the need for collocation or spatial proximity.

Yet, despite this inconsistency, clusters can contribute a great deal to the development of Industry 4.0. A previous study devoted explicitly to clusters' role in the fourth industrial revolution revealed different channels of influence [Götz, Jankowska, 2017]. The peculiarities of knowledge generation and dissemination critical for
Industry 4.0 can be reconciled with the idiosyncratic features of innovation processes typical for clusters. The introduction of new business models triggered by the fourth industrial revolution such as the connected company with vanishing boundaries and the emergence of digital business ecosystems can be detected in mechanisms associated with clusters. Clusters seem to be well-positioned to act as a very promising policy tool organizing the implementation of the fourth industrial revolution and safeguarding the smooth digital transformation of businesses. Clusters can namely act as the laboratories for Industry 4.0 experiments, they provide a conducive environment for knowledge creation and dissemination, they serve as a policy tool for the implementation of advanced projects and are themselves the core of or nodes in the architecture of platforms or networks. The factor of spatial proximity also plays a crucial role. Not all ties with counterparts can be acted upon remotely. Cluster firms adopt the newest IT technologies with respect to the end-customers while they are reluctant to use remote channels for communication with subcontractors, suppliers, and other partners, which should be interpreted as a sign that they rely on flexible and trustworthy informal

\section{Table 5. Comparative Features of Clusters and Industry 4.0}

\begin{tabular}{|l|l|l|}
\hline Dimensions & \multicolumn{1}{|c|}{ Cluster } & \multicolumn{1}{c|}{ Industry 4.0 } \\
\hline Scope & Geographic, location-bound phenomenon & IT-facilitated and dispersed activities \\
\hline Outcomes & $\begin{array}{l}\text { Promote regional and local learning and } \\
\text { production }\end{array}$ & $\begin{array}{l}\text { Worldwide dispersion of activities and allows for connectivity of } \\
\text { geographically scattered units }\end{array}$ \\
\hline Drivers & Agglomeration and specialization & Urbanization and diversification \\
\hline Source: compiled by the author. & \\
\hline
\end{tabular}


communication that cannot be easily and efficiently virtualized in electronic form [Belussi, 2005].

Hence, it might be argued that cluster attributes are the right answer to Industry 4.0 challenges and that the properties of clusters are aligned with Industry 4.0 needs and well positioned to be the drivers for this movement. Nevertheless, those promoted by specific national strategies or appointed within dedicated programs might be particularly suitable.

Consider, for example, German clusters selected in the Leading-Edge Cluster Competition initiated by the Federal Ministry of Education and Research (BMBF) ${ }^{5}$. Selected cases can shed light on the various forms and roles clusters can play with respect to Industry 4.0.

ITS OWL cluster - Intelligent Technical Systems OstWestfalenLippe - in Paderborn represents such a flagship project in Industry 4.0. ITS OWL demonstrates how to harness clusters for digital business transformation. Being an alliance of more than 170 enterprises, universities, laboratories, and other partners, it is working on nearly 50 advanced projects.

CLIB2021 is a Düsseldorf-based cluster having a very diversified portfolio. This is an open innovation alliance active in biotechnology in which approximately $25 \%$ of members are international. It aims at networking stakeholders along and across value chains and in discovering new unexpected value chains in the field of bioeconomy. CLIB2021, while remaining open to external members, simultaneously integrates various sectors (chemical, food, cosmetics, pharmaceutics), works on competences from various areas (IP, access to markets, design etc.) and serves as a platform for joint projects. It further participates in H2020 funded initiatives, offers training opportunities, and establishes outposts in foreign markets.

Similarly, the cluster Netzwerk Smart Production from Manheim is meant chiefly as a tool for regional policy and technology development. Its members include such companies as Roche, SAP, ABB, and E\&Y. The main task of cluster management is to contribute to the advancement of the digitalization of regional businesses, to facilitate networking among partners, and boost cooperation and export performance. Industry 4.0 is perceived as an instrument for making the region a "homeland of innovative pioneers".

On the other hand, the Virtual Dimension Center (VDC) in Fellbach is dedicated to advancing the development of technologies. It is a network for developing digital 3D models comprising of some 100 members dealing with Industry 4.0 processes such as simulation, visualization, product lifecycle management (PLM), computer aided engineering (CAE), and virtual reality (VR) along the entire virtual engineering value chain.
VDC management provides opportunities for seminars and workshops, conducts match-making events, helps companies access relevant information and proper marketing, enables technology transfer, and assists in funding management.

All of these cases demonstrate that there is no standard unified model of an "Industry 4.0 cluster". It is still too early to find any clear evidence of the success of such initiatives, nevertheless, they all help raise awareness and indisputably facilitate the wider reach of Industry 4.0 among SMEs and their employees.

The managers of cluster organizations should play a special role in this respect. In particular, as the case of ITS OWL shows, they need to work not only on ensuring the right accumulation of knowledge and innovation or facilitate the generation of know-how but must also safeguard the transfer of technology and guarantee the right access for all its members. This can materialize by organizing different events, demonstration centers, training and testing, or pilot project presentations. Cluster managers need to prevent possible cluster lock-in due to overspecialization and a lack of diversity. They should provide the necessary openness and inflow of fresh ideas, which are so critical in the rapidly changing business environment of the digital era. They may develop brand and cluster identity as necessary elements for cluster visibility.

The role of universities and other educational bodies also cannot be underestimated [Lis 2018]. Besides achieving academic excellence, they need to closely cooperate with local business and industry to make sure that the curricula and provided courses are aligned with cluster members' expectations, in particular, it is necessary that they address the needs of the local labor market. Specifically, the emerging trend of entrepreneurial universities deserves attention $[\mathrm{Au}-$ dretsch, 2014]. The role they played in the local context can vary but it usually draws on establishing incubators and technology transfer centers or intellectual property spin offs [Pugh et al., 2018]. Besides generating and transferring knowledge, many of these universities are supposed to actively engage in the region by fostering entrepreneurship and entrepreneurial attitudes which can contribute to regional development [Audretsch, Keilbach, 2008; Audretsch, 2014]. All these activities are aimed at enhancing innovativeness and creativity which should translate into the improved efficiency and competitiveness of local entities. Such a role is of even more relevance in the rapidly changing and data-driven analytical age, when close collaboration among academia and industry or business seems to be a condition sine qua non for a smooth transformation of business and society. Obviously, much would depend upon the character of the local innovation sys-

In total there were 15 winners of the Leading-Edge Cluster Competition. For a detailed description see: http://www.clusterplattform.de/CLUSTER/Navigation/EN/Home/home.html. 
tem, whether based on DUI principle - "learning-bydoing, by-using, and by-interacting" or STI - science and technology-based innovation [Jensen et al., 2007]. The DUI system is associated with synthetic knowledge bases (i.e. recombination of different knowledge with a practical, engineering-based purpose) and innovation mostly generated by the capacity to interact with suppliers, customers, and competitors [Fitjar, RodriguezPose, 2013]. The STI system builds upon high R\&D expenditures, investments in highly skilled scientific human resources and advanced technologies and infrastructure, supports interactions with research centers and universities, and as a result, generates mainly analytical knowledge (i.e. scientific principles, discoveries, and formulas).

There is a growing body of literature on the positive externalities of universities in terms of shaping new venture creation [Audretsch et al., 2016]. They might design and develop more vocationally oriented training programs and provide it as part of a lifelong learning initiative. Hence, they would enable the already educated employees of cluster firms to retrain and requalify in order to gain new skills and competences. In Poland for instance, the idea of incubators of Industry 4.0 Leaders" has been developed ${ }^{6}$. Affiliated with Polish technical universities, these incubators aim to promote Industry 4.0 among Polish businesses and industries and to facilitate the uptake of Industry 4.0 mainly among SMEs. The leaders of the technological and digital transformation are trained there in order to act later as multipliers and train the next generation of leaders. Besides providing dedicated module courses, they disseminate information, conduct visits to selected best-practice firms, offer seminars and workshops, ensure access to demonstration models, competence centers and living labs for SMEs, provide consultation services and training as well as assist firms during the implementation phase. It is now worth mentioning the HCAT+ from the Hamburg Aviation Cluster? The Hamburg Centre for Aviation Training works on safeguarding a highly qualified workforce and human capital for the aerospace industry in the region. It sees itself as a coordinator and moderator in terms of training and qualifying personnel. By conducting projects of common interests, it aims to buttress the capabilities especially of SMEs in terms of sustainable human resource development. One of the projects, DigitnetAir, brings together SMEs (responsible for developing new concepts in terms of future Industry 4.0 work), education (schools and universities responsible for developing future oriented and demand driven modules for teaching new skills and competences), and technology (labs and universities in charge of developing and testing new solutions in Industry 4.0 sectors as well as demonstrations and prototypes). DigitnetAir is a unique alliance that aims at countering the negative consequences of qualified labor skill shortages but also at adjusting the teaching and training systems to modern challenges induced by the fourth industrial revolution. It embodies the forward-looking aspects of nurturing the relevant skills by anticipating future trends and predicting local labor market needs in a timely manner.

\section{Conclusions}

Industry 4.0, though it is still used in different contexts and lacks an explicit definition, will certainly revolutionize the global economy [Brettel et al., 2014]. This paper outlines the interdependencies between crucial categories such as: clusters, Industry 4.0, GVCs, networks, and skills. Industry 4.0 transforms global value chains into adaptive networks of interrelated entities. In order for companies to be able to adapt to these processes, their employees need to be equipped with a new set of critical skills. Clusters seem well positioned to foster such an adaptation. Some features of modern production systems and digital transformation embody many of the properties of clusters. The briefly reviewed cases of German Industry 4.0 clusters show how digital production can be arranged via networking within GVCs. These cases confirm our suggestion that in order to be the drivers for Industry 4.0, clusters should stimulate firm's agility which, besides being shaped by the cluster's coopetitive ecosystem, obviously derives from the appropriate competences and skills of its employees.

Companies acting globally and undergoing digital transformation benefit from participation in clusters. The cluster environment fosters agility that allows a company to embed into new value chains and integrated networks.

As our analysis showed, clusters have the potential to ensure a smooth digital business transformation and foster innovation at the local level. They form a "culture of cooperation", contributing to increasing the flexibility of companies by developing such qualities as adaptability, responsiveness, and a combination of responsive strategic and operational management.

Our study aims to expand the knowledge base for the development of regional development programs that take into account the specifics of the target territories and create favorable conditions for networking. This paper, however, does suffer from certain limitations. Using an essay format, it has a more speculative character, though, at current stage of our understanding it may be seen as setting the stage and is an invitation for further research and discussion. The article

\footnotetext{
${ }^{6}$ http://przemysl40.polsl.pl

${ }^{7}$ https://www.hcatplus.de
} 
does not exhaust all other likely interdependencies between these two concepts [Götz, Jankowska, 2017] nor does it finish the discussion on clusters' role in modern global production chains [De Marchi et al., 2018]. The current literature mainly focuses on technical views on digitalization. New alternative channels of "clusters-Industry 4.0 " should be identified and discussed. For instance, the role of the reduction of uncertainty, the importance of clusters as ecosystem for SMEs might deserve scholarly attention. Finally, the idea that clusters would simply result from an Industry-4.0-triggered transformation as assumed by Myrdal cumulative causation [Myrdal, 1953; Smit et al., 2016] should be explored.

This text was drafted as a part of broader research conducted within the framework of the project "Antecedents of the cluster's importance for business digital transformation. How clusters can provide an industrial commons and related variety and how they undergo the stretching process". funded under the Bekker Programme of the Polish National Agency for Academic Exchange (NAWA) - decision no. PPN/BEK/2018/1/00034/DEC/1.

\section{References}

Alcácer J., Cantwell J., Piscitello L. (2016) Internationalization in the information age: A new era for places, firms, and international business networks? Journal of International Business Studies, vol. 47, pp. 499-512. DOI: 10.1057/jibs.2016.22.

Amin A., Cohendet P. (2012) The Firm as a 'Platform of Communities': A Contribution to the Knowledge-based Approach of the Firm. Handbook of Knowledge and Economics (eds. R. Arena, A. Festré, N. Lazaric), Cheltenham: Edward Elgar Publishing, pp. 403-434.

ASTOR (2017) Inżynierowie Przemysłu 4.0 (Nie)gotowi do zmian? [Industry Engineers 4.0 (Un) ready for change?] (ASTOR Whitepaper), Krakow: ASTOR Publishing. Available at: https://www.astor.com.pl/images/Industry_4-0_Przemysl_4-0/ASTOR_Inzynierowie_4.0_ whitepaper.pdf, accessed 03.02.2019 (in Polish).

Audretsch D. (2014) From the entrepreneurial university to the university for the entrepreneurial society. Journal of Technology Transfer, vol. 39, no 3, pp. 313-321. DOI: 10.1007/s10961-012-9288-1.

Audretsch D., Keilbach M. (2008) Resolving the knowledge paradox: Knowledge-spillover entrepreneurship and economic growth. Research Policy, vol. 37, no 10, pp. 1697-1705. DOI: 10.1016/j.respol.2008.08.008.

Audretsch D.B., Lehmann E.E., Menter M. (2016) Public cluster policy and new venture creation. Economia e Politica Industriale, vol. 43, no 4, pp. 357-381. Available at: https://doi.org/10.1007/s40812-016-0050-9, accessed 03.02.2019.

BDI (n.d.) What is Industry 4.0. Available at: https://english.bdi.eu/topics/germany/industrie-40/, accessed 15.01.2019.

Belussi F. (2005) Are Industrial Districts Formed by Networks without Technologies? European Urban and Regional Studies, vol. 12, no 3, pp. 247-268.

Bosch (2014) Bosch pools Industry 4.0 expertise in the "Connected Industry" innovation cluster. Available at: https://www.bosch-presse.de/ pressportal/de/en/bosch-pools-industry-4-0-expertise-in-the-connected-industry-innovation-cluster-42906.html, accessed 21.04.2019.

Bramanti A. (2016) New Manufacturing Trends in Developed Regions. Three Delineations of New Industrial Policies: 'Phoenix Industry', 'Industry 4.0', and 'Smart Specialisation' (Working Paper), Milano: Bocconi University. DOI: 10.13140/RG.2.2.30402.99522.

Brettel M., Friederichsen N., Keller M., Rosenberg M. (2014) How Virtualization, Decentralization and Network Building Change the Manufacturing Landscape: An Industry 4.0 Perspective, World Academy of Science, Engineering and Technology. International Journal of Mechanical, Aerospace, Industrial, Mechatronic and Manufacturing Engineering, vol. 8, no 1, pp. 37-44.

Brodzicki T., Dzierżanowski M., Szultka S. (2005) Cluster-based Policy for Mazovia Region, Gdańsk: IBnGR Press.

Chen W., Kamal F. (2016) The Impact of Information and Communication Technology Adoption on Multinational Firm Boundary Decisions. Journal of International Business Studies, vol. 47, no 5, pp. 563-576.

Christopher M. (2000) The Agile Supply Chain. Industrial Marketing Management, vol. 29, no 1, pp. 37-44.

Cooke P. (2001) Regional innovation systems, clusters, and the knowledge economy. Industrial and Corporate Change, vol. 10, no 4, pp. 945-974.

Črešnar R., Jevšenak S. (2019) The Millennials' Effect: How Can Their Personal Values Shape the Future Business Environment of Industry 4.0? Naše Gospodarstvo/Our Economy, vol. 65, no 1, pp. 57-65. DOI: 10.2478/ngoe-2019-0005.

D’Aveni R.A. (1998) Waking up to the new era of hypercompetition. The Washington Quarterly, vol. 21, no 1, pp. $183-195$.

Davidow W., Malone M. (1992) The Virtual Corporation, New York: Harper Collins.

De Marchi V., Di Maria E., Gereffi G. (2018) Local Clusters in Global Value Chains Linking Actors and Territories Through Manufacturing and Innovation. New York: Routledge. Available at: https://www.routledge.com/Local-Clusters-in-Global-Value-Chains-Linking-Actorsand-Territories-Through/De-Marchi-Di-Maria-Gereffi/p/book/9781138742864, accessed 22.03.2019.

Delgado M., Porter M.E., Stern S. (2014) Defining clusters of related industries (NBER Working Paper 20375), Cambridge, MA: National Bureau of Economic Research. Available at: http://www.nber.org/papers/w20375, accessed 15.03.2019.

Drath R., Horch A. (2014) Industrie 4.0: Hit or Hype? IEEE Industrial Electronics Magazine, vol. 8, no 2, pp. 56-58. DOI: 10.1109/ MIE.2014.2312079.

Ellison G., Glaeser E.L. (1997) Geographic concentration in U.S. manufacturing industries: A dartboard approach. Journal of Political Economy, vol. 105, pp. 889-927.

European Commission (2016) The Story of the European Cluster Conference 2016. Clusters 4.0: Shaping Smart Industries. Key Policy Messages, Brussels: European Commission. Available at: http://www.choruscluster.org/img/The-story-ECC-2016.pdf, accessed 27.02.2019.

Fitjar R.D., Rodríguez-Pose A. (2013) Firm collaboration and modes of innovation in Norway. Research Policy, vol. 42, no 1, pp. $128-138$.

Folkerts-Landau D., Schneider S. (2016) Beacon of stability: The foundations of Germany's success, Frankfurt am Main: Deutsche Bank Research.

Forsgren M. (2016) A note on the revisited Uppsala internationalization process model - the implications of business networks and entrepreneurship. Journal of International Business Studies, vol. 47, no 9, pp. 1135-1144. DOI: 10.1057/s41267-016-0014-3. 
Forsgren M., Hagg I., Hakansson H., Johanson J., Mattsson L. (1995) Firms in networks: A new perspective on competitive power, Uppsala: Uppsala University.

Foster C.G., Graham M. (2016) Reconsidering the Role of the Digital in Global Production Networks. Global Networks, vol. 17, no 1, pp. $68-88$.

Götz M. (2009) Atrakcyjność klastra dla lokalizacji bezpośrednich inwestycji zagranicznych [Cluster attractiveness for the localisation of foreign investments], Poznań: Wydawnictwo Instytutu Zachodniego [Western University Publishing] (in Polish).

Götz M., Jankowska B. (2017) Clusters and Industry 4.0 - do they fit together? European Planning Studies, vol. 25, no 9, pp. $1633-1653$. DOI: 10.1080/09654313.2017.1327037.

Grzybowska K., Łupicka A. (2017) Key competencies for Industry 4.0. Economics \& Management Innovations (ICEMI) Conference Proceedings, vol. 1, no 1, pp. 250-253.

GTI (n.d.) Industrie 4.0 - What is It? Available at: https://www.gtai.de/GTAI/Navigation/EN/Invest/Industries/Industrie-4-0/Industrie-40/industrie-4-0-what-is-it.html, accessed 15.01.2019.

Gunasekaran A. (1998) Agile manufacturing: Enablers and an implementation framework. International Journal of Production Research, vol. 36, no 5, pp. 1223-1247.

Hermann M., Pentek T., Otto B. (2015) Design Principles for Industrie 4.0 Scenarios: A Literature Review (Working Paper 01), Dortmund: Technische Universität Dortmund. Available at: www.snom.mb.tu-dortmund.de http://www.snom.mb.tu-dortmund.de/cms/de/ forschung/Arbeitsberichte/Design-Principles-for-Industrie-4_0-Scenarios.pdf , accessed 15.01.2016.

Hessami G. (2017) Industrie 4.0, Firmen verstolpern den großen Wurf [Industry 4.0, companies stumble the big hit], Handelsblatt Online, 17.03.2017. Available at: https://www.handelsblatt.com/technik/it-internet/cebit2017/industrie-4-0-firmen-verstolpern-den-grossenwurf/19424842.html?ticket=ST-94733-uqQOiFsAQ43PibLLn74T-ap3, accessed 14.02.2019 (in German).

Hüther M. (2016) Digitalisation: An engine for structural change - A challenge for economic policy (IW policy paper 15/2016), Koeln: Institut der Deutsche Wirtschaft. Available at: https://www.iwkoeln.de/en/studies/beitrag/michael-huether-digitalisierung-systematisierung-dertrends-im-strukturwandel-gestaltungsaufgabe-fuer-die-wirtschaftspolitik-317419, accessed 19.12.2016.

Immink R. (2015) Networked organisations will become the new normal. Available at: https://www.ronimmink.com/tworked-organisationswill-become-the-new-normal/, accessed 19.02.2019.

Jensen M.B., Johnson B., Lorenz E., Lundvall B.Å. (2007) Forms of knowledge and modes of innovation. Research Policy, vol. 36 , pp. 680-693.

Johanson J., Mattsson L.G. (1997) Interorganizational relations in industrial systems. A network approach compared with the transactioncost approach, International Studies of Management and Organization, vol. 17, no 1, pp. 34-48.

Johanson J., Vahlne J.E. (2009) The Uppsala internationalization process model revisited: From liability of foreignness to liability of outsidership. Journal of International Business Studies, vol. 40, no 9, pp. 1411-1431.

Kagermann H., Wahlster W., Helbig J. (2013) Umsetzungsempfehlungen für das Zukunftsprojekt Industrie 4.0 [Implementation recommendations for the future project Industry 4.0], Frankfurt/Main: Acatech (in German).

Kenney M., Zysman J. (2016) The Rise of the Platform Economy. Issues in Science and Technology, vol. 32, no 3, pp. 61-69.

Ketels C. (2004) European Clusters. Innovative City and Business Regions. Vol. 3 - Structural Change in Europe, Bollschweil: Hagbrath Publications, pp. 1-5. Available at: https://abclusters.org/wp-content/uploads/2013/12/Ketels_European_Clusters_20041.pdf, accessed 14.02.2019.

Kinkel S., Rahn J., Rieder B., Lerch C., Jäger A. (2016) Digital-vernetztes Denken in der Produktion [Digital networked thinking in production] (Studie für die IMPULS-Stiftung des VDMA), Karlsruhe: Hochschule Karlsruhe - Technik und Wirtschaft; Fraunhofer-Institut für System- und Innovationsforschung (ISI) (in German).

Klös H.P. (2016) Arbeiten in der digitalen Welt [Jobs in the digital world]. IW Koeln Website, 15.01.2016. Available at: https://www. iwkoeln.de/presse/in-den-medien/beitrag/hans-peter-kloes-in-der-ihk-zeitschrift-arbeiten-in-der-digitalen-welt-261424.html, accessed 12.03.2019 (in German).

Krugman P. (1991) Increasing Returns and Economic Geography. Journal of Political Economy, vol. 99, no 3, pp. 483-499.

Kumar M., Fowler S., Fytatzi K. (2016) International: Industry 4.0 will arrive unevenly. OxResearch Daily Brief Service, 12.10.2016. Available at: https://dailybrief.oxan.com/Analysis/DB214240/Industry-40-will-arrive-unevenly, accessed 02.05.2019.

Liao Y., Deschamps F., de Freitas E., Loures F., Ramos L.F.P. (2017) Past, present and future of Industry 4.0 - A systematic literature review and research agenda proposal. International Journal of Production Research, vol. 55, no 12, pp. 410-426.

Lis A.M. (2018) Współpraca w inicjatywach klastrowych. Rola bliskości w rozwoju powiązań kooperacyjnych [Cooperation in cluster initiatives. The role of intimacy in the development of cooperative relations], Gdańsk: Wydawnictwo Politechniki Gdańskiej [Gdansk University of Technology Publishing] (in Polish).

Lydon B. (2016) Industry 4.0: Intelligent and flexible production. INTECH, vol. 63, no 3, pp. 12-17. Available at: http://search.proquest.com/ docview/1799786990?accountid=168796, accessed 12.11.2018.

Manyika J., Lund S., Bughin J., Woetzel J., Stamenov K., Dhingra D. (2016) Digital globalization: The new era of global flows, New York: McKinsey Global Institute.

Marshall A. (1920) Principles of Economics, London: MacMillan.

Maskell P., Lorenzen M. (2003) The Cluster as Market Organization (DRUID Working Paper No 03-14), Copenhagen: Copenhagen Business School.

Meredith S., Francis D. (2000) Journey towards agility: The agile wheel explored. TQM Magazine, vol. 12, no 2, pp. $137-143$.

Mesnard X. (2016) What happens when robots take our jobs? Available at: http://www.weforum.org/agenda/2016/01/what-happens-whenrobots-take-our-jobs, accessed 12.03.2019.

Mikusz M. (2014) Towards an understanding of cyber-physical systems as industrial software-product-service systems. Procedia CIRP, vol. 16, pp. 385-389.

Morisse M., Prigge C. (2017) Design of a business resilience model for Industry 4.0 manufacturers. Paper presented at the AMCIS Conference 2017, August 10-12, Boston, USA.

Myrdal G. (1953) The Political Element in the Development of Economic Theory, London: Routledge; Kegan Paul.

Njøs R., Jakobsen S.E., Aslesen H.W., Fløysand A. (2016) Encounters between cluster theory, policy and practice in Norway: Hubbing, blending and conceptual stretching. European Urban and Regional Studies, vol. 24, no 3, pp. 274-289. 
Overman M., Redding S., Venables A. (2001) The Economic Geography of Trade Production and Income: A Survey of Empirics (CEPR Discussion Paper 2978), London: Centre for Economic Policy Research.

Pedersen Ch. (2005) The Development Perspectives for the ICT sector in North Jutland (PhD Thesis), Aalborg: Aalborg University.

Porter M.E. (2000) Location, Competition, and Economic Development: Local Clusters in a Global Economy. Economic Development Quarterly, vol. 14, no 1, pp. 15-34.

Prause G. (2015) Sustainable business models and structures for industry 4.0. Journal of Security and Sustainability, vol. 5, no 2, pp. 159-169.

Pugh R., Lamine W., Jack S., Hamilton E. (2018) The entrepreneurial university and the region: What role for entrepreneurship departments? European Planning Studies, vol. 26, no 9, pp. 1835-1855. DOI: 10.1080/09654313.2018.1447551.

Qin J., Liu Y., Grosvenor R. (2016) A Categorical Framework of Manufacturing for Industry 4.0 and Beyond. Procedia CIRP, vol. 52, pp. 173-178.

Rangan S., Sengul M. (2009) Information Technology and Transnational Integration: Theory and Evidence on the Evolution of the Modern Multinational Enterprise. Journal of International Business Studies, vol. 40, no 9, pp. 1496-1514.

Ratajczak-Mrozek M. (2010) Sieci biznesowe a przewaga konkurencyjna przedsiębiorstw zaawansowanych technologii na rynkach zagranicznych [Business networks and the competitive advantage of advanced technology enterprises on foreign markets], Poznań: Wydawnictwo Uniwersytetu Ekonomicznego w Poznaniu [Poznań University of Economics and Business Publishing] (in Polish).

Roblek V., Meško M., Krapež A. (2016) A Complex View of Industry 4.0. SAGE Open, April-June issue, pp. 1-11. DOI: $10.1177 / 2158244016653987$.

Romanowska M. (2004) Planowanie strategiczne w przedsiębiorstwie [Corporate strategic planning], Warszawa: PWE (in Polish).

Rosenkopf L., Almeida P. (2003) Overcoming local search through alliances and mobility. Management Science, vol. 49, no 6, pp. 751-766.

Rüßmann M., Lorenz M., Gerbert P., Waldner M., Justus J., Engel P., Harnisch M. (2015) Industry 4.0: The Future of Productivity and Growth in Manufacturing Industries, Boston, MA: Boston Consulting Group. Available at: http://www.inovasyon.org/pdf/bcg.perspectives_ Industry.4.0_2015.pdf, accessed 16.04.2019.

Sajdak M. (2014) Zwinność jako źródło przewagi konkurencyjnej i sukcesu przedsiębiorstwa [Agility as a source of competitive advantage and business success], Prace Naukowe Uniwersytetu Ekonomicznego we Wroclawiu [Research Papers of the Wroclaw University of Economics], vol. 358, pp. 58-70. Available at: http://jmf.wzr.pl/pim/2013_4_1_20.pdf, accessed 25.03.2018 (in Polish).

SAP (2017) Industry 4.0 - What's Next. Available at: https://www.sap.com/documents/2017/05/bae613d3-b97c-0010-82c7eda71af511fa.html, accessed 15.01.2019.

Schmidt R., Möhring M., Härting R.C., Reichstein C., Neumaier P., Jozinović P. (2015) Industry 4.0 - Potentials for Creating Smart Products: Empirical Research Results. Business Information Systems (ed. W. Abramowicz), Heidelberg; New York; Dordrecht; London: Springer, pp. 16-27. DOI: 10.1007/978-3-319-19027-3_2.

Schuh G., Potent T., Wesch-Potent C., Webe A., Prote J.P. (2014) Collaboration Mechanisms to increase Productivity in the Context of Industrie 4.0. Procedia CIRP, vol. 19, pp. 51-56.

Smit J., Kreutzer S., Moeller C., Carlberg M. (2016) Industry 4.0, Brussels: European Parliament. Available at: http://www.europarl.europa. eu/RegData/etudes/STUD/2016/570007/IPOL_STU(2016)570007_EN.pdf, accessed 15.02.2019.

Sölvell Ö. (2009) Clusters - Balancing Evolutionary and Constructive Forces, Stockholm: Ivory Tower Publishers.

Sorenson O. (2003) Social networks and industrial geography. Journal of Evolutionary Economics, vol. 13, no 1, pp. 513-527.

Strange R., Zucchella A. (2017) Industry 4.0, global value chains and international business. Multinational Business Review, vol. 25, no 3, pp. 174-184.

Thorelli H.B. (1986) Networks: Between Markets and Hierarchies. Strategic Management Journal, vol. 7, no 1, pp. 37-51.

Timmer M.P., Los B., Stehrer R., de Vries G.J. (2013) Fragmentation, incomes and jobs: An analysis of European competitiveness. Economic Policy, no 28 (76), pp. 613-661.

UNCTAD (2017) World Investment Report 2017 - Investment and the Digital Economy, Geneva: UNCTAD.

Warnecke H.J. (1997) The Fractal Company, A Revolution in Corporate Culture, Heidelberg; New York; Dordrecht; London: Springer. 